\title{
Anxiety, depression and impaired quality of life in primary aldosteronism: Why we shouldn't ignore it!
}

Martin Reincke, $\mathrm{MD}^{1}$

${ }^{1}$ Medizinische Klinik und Poliklinik IV, Klinikum der Universität München, Ziemssenstraße 1, 80331 München, Germany

\section{Corresponding author:}

Prof. Martin Reincke, Medizinische Klinik und Poliklinik IV, Klinikum der Universität, München, Ziemssenstraße 1, 80331 München, Deutschland, Tel: +49-(89)-440052411, e-mail: martin.reincke@med.uni-muenchen.de

DISCLOSURE STATEMENT: The authors have nothing to disclose

Short title: $\quad$ Quality of Life in PA

Keywords: $\quad$ Conn's syndrome, anxiety, depression, aldosterone, hypercortisolism

Word count: 1706 (without references)

Table: 1

\section{Funding:}

This work was supported by the European Research Council (ERC) under the European Union's Horizon 2020 research and innovation programme (grant agreement No [694913] to MR), the Else Kröner-Fresenius Stiftung in support of the German Conns Registry-Else-Kröner Hyperaldosteronism Registry (2013_A182 and 2015_A171 to MR) and the Deutsche Forschungsgemeinschaft (RE 752/20-1 to MR). 


\section{Introduction}

Many endocrinopathies are associated with impaired quality of life and psychiatric comorbidities. Personality changes are characteristic features of endocrine diseases and can even be the dominating symptom. In such circumstances, a patient will be treated for an apparent primary psychiatric condition whereas the underlying endocrine diagnosis is delayed for month or even years. It is textbook knowledge that mania and psychosis may be found in patients with severe hyperthyroidism, whereas patients with Cushing's syndrome suffer frequently from depressive symptoms and cognitive disturbances. In pituitary diseases the spectrum depends on the underlying hyper- or hypofunction: Acromegalic patients have often maladaptive personality traits and higher rates of affective disorders, and patients with prolactinoma have changes in sleep pattern and cognition.

\section{Anxiety and depression in primary aldosteronism: often overlooked}

Primary aldosteronism affects - depending on hypertension prevalence in the respective target populations - 1 to $2 \%$ of the general population (1). It comes with an increased risk of cardiovascular and renal comorbidities compared to hypertensives of similar age, sex and blood pressure. Contrary to other endocrinopathies psychiatric co-morbidities in patients with primary aldosteronism have only recently become a focus of attention.

Several early case reports identified depression and anxiety disorders as symptoms associated with primary aldosteronism (2-5). It took until 2006 that Sonino et al. investigated 10 consecutive patients with primary aldosteronism using the Structured Clinical Interview for the Diagnostic and Statistical Manual of Mental Disorders (DSMIV) and the Diagnostic Criteria for Psychosomatic Research interview (6). As it tuned out, seven patients qualified for the diagnosis of a generalized anxiety disorder and one patient had an obsessive-compulsive disorder (Table 1). The patients also reported demoralization $(n=5)$, persistent somatization $(n=2)$ and irritable mood $(n=1)$. In a controlled study, the same authors confirmed this finding in an independent cohort of 23 patients with primary aldosteronism in comparison to matched essential hypertensives and normotensive controls (7). Again, there was a striking prevalence of anxiety and to a lesser degree depression in the patients.

In a large cross-sectional study we studied 132 patients with primary aldosteronism in different phases of the disease: at diagnosis before initiation of specific treatment, 4 years after adrenalectomy, or 5 years after initiation of mineralocorticoid antagonist treatment (8). We assessed anxiety and depression by the validated questionnaires GAD-7 and PHQD. Compared to the normal German population patients with primary aldosteronism had higher prevalence rates for depression and anxiety, with females being more severely affected than males. 


\section{Impaired quality of life in primary aldosteronism: is adrenalectomy better than mineralocorticoid antagonist treatment?}

The first study to investigate the longitudinal impact of adrenalectomy and mineralocorticoid antagonist treatment on quality of life was the Stowasser group from Australia. In their pilot study, quality of life was evaluated prospectively using the SF-36 questionnaire before and 3 and 6 months after unilateral adrenalectomy in 22 patients with primary aldosteronism (9). Pre-operatively, the patients had impaired quality of life in each quality of life domain compared to the Australian general population. Significant improvements were seen as early as 3 months after surgery, and to a similar degree 6 month after adrenalectomy. In a parallel protocol involving 21 subjects with bilateral adrenal hyperplasia treated with spironolactone or amiloride quality of life at three month was again lower compared to adrenalectomized patients but normalized at 6 month (10). In summary, these studies suggested that the outcome of surgically and medically treated patients might be similar in terms of quality of life. However, limitations of both studies have been the relative short followup and the limited number of subjects studied. Hence, whether long-term quality of life outcome of medical treatment is equivalent to adrenalectomy remained an open question. Since cardiovascular and renal outcomes seem to be similar between surgical and medical treatment (11) quality of life might become the only justification for surgery.

In the study by Valema et al. published in this issue of JCEM the authors investigated quality of life in patients of the SPARTACUS trial (12). This was a randomized trial performed in 200 patients with primary aldosteronism in 12 Dutch centers and one Polish center. The primary objective of this trial was to compare the blood pressure outcome of computed tomography-based subtyping with that of adrenal vein sampling based subtyping. Surprisingly, blood pressure outcome (quantified as daily defined doses) was similar in both groups with a non-significant difference of remission rates. 92 patients were subjected to unilateral adrenalectomy, and 92 patients to treatment with mineralocorticoid antagonist, and the authors used this cohort to analyze quality of life prospectively 6 and 12 month after start of therapy. Quality of life prior initiation of treatment was low in both groups, in line with the Stowasser group data, indicating a significant disease burden. Of note, female patients had worse scores than males. Quality of life improved substantially in both treatment arms although to a lesser degree in the MRA group. At last follow-up after 12 month quality of life of the surgery group was equivalent or better that that of the normal population. In contrast, patients with bilateral adrenal hyperplasia treated with mineralocorticoid antagonists had improvements in quality of life without full recovery. More importantly, the surgery group had clinical meaningful higher scores than the mineralocorticoid antagonist group. In summary, based on quality of life this large prospective study is in favor of adrenalectomy. This could be a strong argument for screening and subtyping of primary aldosteronism: find the patient with unilateral aldosteronism, since long-term quality of life is better than putting the patient on mineralocorticoid antagonist therapy. That screening and subtyping of primary aldosteronism in general is a cost-effective, has been recently shown (13). 


\section{Pathways by which aldosterone excess induce anxiety and depression and may impair quality of life}

Currently it remains an open question whether depression, anxiety and consecutively impaired quality of life are direct consequences of aldosterone excess via endocrine effects on the brain or result from uncontrolled hypertension. Evidence can be found for both concepts. The mineralocorticoid receptor function in the CNS has been implicated in the response to antidepressive treatment and in the mediation of anxiety related behavior. Moreover, the mineralocorticoid receptor seems also to be involved in emotional memory processes (as reviewed by Künzel (14)). A recent paradigm shift has been the implication of direct aldosterone actions at the level of mineralocorticoid receptors in the CNS. Formerly thought to be occupied by glucocorticoids in most parts of the brain, there is accumulating evidence that aldosterone acts selectively in relevant mood-regulating brain areas, without competing with cortisol/corticosterone (reviewed by (15)). In a rat model of depression subcutaneous aldosterone given via somotic minipumps induced an anhedonic state manifested by decreased sucrose preference, and a depression-like behavior in the forced swim test (16). On the other hand, besides direct aldosterone actions on the brain, uncontrolled or treatment resistant hypertension by itself could be a major factor causing anxiety and impaired quality of life (17). Patients with primary aldosteronism report of frequent visits to outpatient clinics for drug adjustments and unsuccessful attempts to reach blood pressure targets. They may have hypertensive emergencies, and suffer from insecurities resulting from high blood pressure readings when performing home blood pressure measurements. Resistant hypertension also could lead to cerebrovascular impairment and white matter lesions, in line with the 'vascular hypothesis' of depression (14).

An alternative explanation comes from the steroid secretion patterns in primary aldosteronism. Using a mass spectrometry-based analysis of the 24-hour urine steroid metabolome in 174 patients with newly diagnosed primary aldosteronism we have recently reported significant cortisol co-secretion in the majority of patients (18). Quantitatively, the glucocorticoid excess was more pronounced than that found in so called subclinical Cushing's syndrome (now termed autonomous cortisol secretion) but less than that typical for full-blown adrenal Cushing's syndrome. Unilateral adrenalectomy abolished aldosterone excess and normalized glucocorticoid cosecretion. Based on the simultaneous presence of Cushing's and Conn's syndrome we termed this endocrine constellation Connshing's syndrome. It is an attractive concept, that cortisol co-secretion might be detrimental for psychological well-being in untreated primary aldosteronism, and it could explain differences in quality of life in response to surgery or medical treatment. While adrenalectomy removes both mineralocorticoid and glucocorticoid excess, patients treated with mineralocorticoid receptor antagonist might have persistent and un-opposed glucocorticoid excess negatively affecting quality of life. 


\section{References}

1. Asbach E, Williams TA, Reincke M 2016 Recent Developments in Primary Aldosteronism. Exp Clin Endocrinol Diabetes.;124:335-41. doi: 10.1055/s-0042105278.

2. Malinow KC, Lion JR1979 Hyperaldosteronism (Conn's disease) presenting as depression. J Clin Psychiatry. Aug;40:358-9.

3. Avery TL 1984 Primary hyperaldosteronism and depression. N Z Med J. 8;97:537.

4. Khurshid K A , Weaver M E 2005 Conn's syndrome presenting as depression. Am J Psychiatry; $162: 1226$.

5. Tritos N A 2007 Diagnosis of primary aldosteronism in a patient with an incidentally found adrenal mass. Nat Clin Pract Endocrinol Metab; 3: 547 - 551.

6. Sonino N, Fallo F, Fava GA 2006 Psychological aspects of primary aldosteronism. Psychother Psychosom;75:327-30.

7. Sonino N, Tomba E, Genesia ML, Bertello C, Mulatero P, Veglio F, Fava GA, Fallo F 2011 Psychological assessment of primary aldosteronism: a controlled study. J Clin Endocrinol Metab.;96:E878-83. doi: 10.1210/jc.2010-2723.

8. Apostolopoulou K, Künzel HE, Gerum S, Merkle K, Schulz S, Fischer E, Pallauf A, Brand V, Bidlingmaier M, Endres S, Beuschlein F, Reincke M 2014 Gender differences in anxiety and depressive symptoms in patients with primaryhyperaldosteronism: a cross-sectional study. World J Biol Psychiatry.;15:26-35. doi: 10.3109/15622975.2012.665480.

9. Sukor N, Kogovsek C, Gordon RD, Robson D, Stowasser M 2010 Improved quality of life, blood pressure, and biochemical status following laparoscopic adrenalectomy for unilateral primary aldosteronism. J Clin Endocrinol Metab.; 95:1360-4. doi: 10.1210/jc.2009-1763.

10. Ahmed AH, Gordon RD, Sukor N, Pimenta E, Stowasser M 2011 Quality of life in patients with bilateral primary aldosteronism before and during treatment with spironolactone and/or amiloride, including a comparison with our previously published results in those with unilateral disease treated surgically. J Clin Endocrinol Metab.;96:2904-11. doi: 10.1210/jc.2011-0138.

11. Funder JW, Carey RM, Mantero F, Murad MH, Reincke M, Shibata H, Stowasser M, Young WF Jr 2016 The Management of Primary Aldosteronism: Case Detection, Diagnosis, and Treatment: An Endocrine Society Clinical Practice Guideline. J Clin Endocrinol Metab.;101:1889-916. doi: 10.1210/jc.2015-4061.

12. Velema et al 2017 , JCEM 
13. Lubitz CC, Economopoulos KP, Sy S, Johanson C, Kunzel HE, Reincke M, Gazelle GS, Weinstein MC, Gaziano TA 2015 Cost-Effectiveness of Screening for Primary Aldosteronism and Subtype Diagnosis in the Resistant Hypertensive Patients. Circ Cardiovasc Qual Outcomes.;8:621-30. doi: 10.1161/CIRCOUTCOMES.115.002002.

14. Künzel HE 2012 Psychopathological symptoms in patients with primary hyperaldosteronism--possible pathways. Horm Metab Res.;44:202-7. doi: 10.1055/s-0032-1301921.

15. Murck H, Büttner M, Kircher T, Konrad C 2014 Genetic, molecular and clinical determinants for the involvement of aldosterone and its receptors in major depression. Nephron Physiol.;128:17-25. doi: 10.1159/000368265.

16. Hlavacova N, Wes PD, Ondrejcakova M, Flynn ME, Poundstone PK, Babic S, Murck H, Jezova D 2012 Subchronic treatment with aldosterone induces depression-like behaviours and gene expression changes relevant to major depressive disorder. Int $\mathrm{J}$ Neuropsychopharmacol.;15:247-65. doi: 10.1017/S1461145711000368.

17. Carris NW, Smith SM 2015 Quality of Life in Treatment-Resistant Hypertension. Curr Hypertens Rep.;17(8):61. doi: 10.1007/s11906-015-0578-5.

18. Arlt W, Lang K, Sitch AJ, Dietz AS, Rhayem Y, Bancos I, Feuchtinger A, Chortis V, Gilligan LC, Ludwig P, Riester A, Asbach E, Hughes BA, O'Neil DM, Bidlingmaier M, Tomlinson JW, Hassan-Smith ZK, Rees DA, Adolf C, Hahner S, Quinkler M, Dekkers T, Deinum J, Biehl M, Keevil BG, Shackleton CHL, Deeks JJ, Walch AK, Beuschlein F, Reincke M 2017 Steroid metabolome analysis reveals prevalent glucocorticoid excess in primary aldosteronism. JCl Insight.;2. pii: 93136. doi: 10.1172/jci.insight.93136. [Epub ahead of print] 
Table 1: Prevalence of depression, anxiety and impaired quality of life in patients with primary aldosteronism

\begin{tabular}{|c|c|c|c|c|}
\hline \multicolumn{5}{|c|}{ Depression and Axiety } \\
\hline & $\begin{array}{l}\text { Author, year, } \\
\text { questionnaire used }\end{array}$ & Population & Depression & Anxiety disorder \\
\hline (6) & $\begin{array}{l}\text { Sonino, Fallo \&Fava } \\
\text { (2006); DSM-IV, DCPR }\end{array}$ & 10 patients with PA & $10 \%$ & $70 \%$ \\
\hline (7) & $\begin{array}{l}\text { Sonino et al. (2012); DSM- } \\
\text { IV, DCPR, PSI, SQ }\end{array}$ & $\begin{array}{l}23 \text { patients with } \mathrm{PA} \\
\text { versus } \\
23 \text { patients with } \mathrm{EH} \\
\text { versus } \\
23 \text { normotensive controls }\end{array}$ & $\begin{array}{l}30 \% \\
22 \% \\
0 \%\end{array}$ & $\begin{array}{l}52 \% \\
17 \% \\
4 \%\end{array}$ \\
\hline (8) & $\begin{array}{l}\text { Apostolopoulou et al. } \\
\text { (2012); PHQD, GA/7 }\end{array}$ & $\begin{array}{l}27 \text { patients with florid PA } \\
56 \text { with chronic MRA therapy } \\
49 \text { after adrenalectomy ( } 4.3 \text { years later) } \\
\text { German reference population }\end{array}$ & $\begin{array}{l}25 \% \\
10 \% \\
5 \% \\
7 \%\end{array}$ & $\begin{array}{l}50 \% \\
48 \% \\
44 \% \\
\text { n.a. }\end{array}$ \\
\hline \multicolumn{5}{|c|}{ Quality of Life } \\
\hline & $\begin{array}{l}\text { Author, publication year, } \\
\text { questionnaire used }\end{array}$ & Population and intervention & $\begin{array}{l}\text { QoL at time of } \\
\text { diagnosis }\end{array}$ & QoL at follow-up \\
\hline (9) & Sukor et al. (2010); SF-36 & $\begin{array}{l}22 \text { patients with unilateral PA, } \\
\text { adrenalectomy }\end{array}$ & $\begin{array}{l}\text { QoL scores reduced } \\
\text { compared to general } \\
\text { population for } \\
\text { physical functioning, } \\
\text { role physical, vitality, } \\
\text { and general health }\end{array}$ & $\begin{array}{l}\text { QoL improved at } 6 \\
\text { month for physical } \\
\text { functioning, role } \\
\text { physical, general } \\
\text { health, role emotional, } \\
\text { mental health, and } \\
\text { vitality }\end{array}$ \\
\hline (10) & Ahmed et al. (2011); SF-36 & $\begin{array}{l}21 \text { patients with bilateral } \mathrm{PA}, \mathrm{MRA} \\
\text { treatment }\end{array}$ & $\begin{array}{l}\text { QoL scores reduced } \\
\text { compared to the } \\
\text { general population } \\
\text { for physical } \\
\text { functioning, role } \\
\text { limitations general } \\
\text { health perceptions, } \\
\text { vitality }\end{array}$ & $\begin{array}{lr}\text { QoL } & \text { scores } \\
\text { significantly } & \text { improved } \\
\text { for } & \text { physical } \\
\text { functioning, } & \text { role } \\
\text { limitations, } & \text { general } \\
\text { health, vitality } & \end{array}$ \\
\hline$(11)$ & $\begin{array}{l}\text { Velema et al. (2017); SF- } \\
36\end{array}$ & $\begin{array}{l}92 \text { patients with unilateral PA, } \\
\text { adrenalectomy } \\
92 \text { patients with bilateral PA, MRA } \\
\text { treatment }\end{array}$ & $\begin{array}{l}\text { Reduced physical } \\
\text { and mental QoL } \\
\text { compared to normal } \\
\text { population } \\
\text { Reduced physical } \\
\text { and mental QoL } \\
\text { summary compared } \\
\text { to normal population }\end{array}$ & $\begin{array}{l}\text { Normalized QoL } \\
\text { compared to normal } \\
\text { population } \\
\text { Improved, but } \\
\text { compared to unilateral } \\
\text { PA physical and } \\
\text { mental QoL lower }\end{array}$ \\
\hline
\end{tabular}

$\mathrm{PA}=$ Primary aldosteronism; MRA = mineralocorticoid receptor antagonist treatment; $\mathrm{n} . \mathrm{a} .=$ not available; $\mathrm{PHQD}=$ brief patient health questionnaire ; GAD-7 general anxiety disorder questionnaire; the Structured Clinical Interview for Diagnostic and Statistical Manual of Mental Disorders (DSM-IV); Diagnostic Criteria for Psychosomatic Research (DCPR); Psychosocial Index (PSI); the Symptom Questionnaire (SQ); SF-36 = Medical Outcomes Study Short Form 36 General Health Survey; EQ-5D = European Quality of Life-5 Dimensions instrument. 